\title{
Character education based on six value system
}

\author{
Abduloh $^{*}$ \\ Universitas Singaperbangsa Karawang, Fakultas Keguruan dan Ilmu Pendidikan \\ J1.Hs Ronggo Waluyo Teluk Jambe Timur Karawang Jawa Barat Indonesia 41361
}

\begin{abstract}
Humans are social beings who mutually cooperate and interact with each other that have an impact on the changes and dynamics of a complex life, both individually and in groups that may be able to uphold the value and dignity and vice versa, it can be influenced by individual and group characteristics in living his life. The purpose of this study is to describe the application and outcome of character education based on six value systems. This study applied descriptive method with literature review analysis. The results of the analysis show that the character of education based on the six value systems can be applied in various levels of education from basic education to higher education and educational outcomes can have the characteristics of value for use, or benefits for the life of the community worthy both materially and spiritually that can solve the problem, Improvement and change of valuable moral, mental, and spiritual skills.
\end{abstract}

\section{Introduction}

Modernization is one of the characteristics of the cultural development which is balanced with the development of science and technology very rapidly, related to the increasingly complex human life behavior so that it can cause share the problem. The problem if not balanced with a valuable education that becomes a character in the learning process that is able to print changes in knowledge, attitude and human skills that are able to solve various problems and challenges of life. To overcome the challenges that are problematic in the learning process is expected learners can have the skills, Benjamin Bloom (1956) suggests knowledge (cognitive skills), attitude skills (affective skills), and Phsicomotoric skills' (Susanti 1995). ${ }^{[1]}$

Character education should bring learners to cognitive value recognition, appreciation of value affectively, and ultimately to actual value practice. This is the design of moral character education (moral knowing), moral feeling), and moral action (Lickona, 1991: $51)^{[2]}$ Therefore, all subjects studied by learners in schools should be character-educated characters that can bring human beings who have the character of personality and noble character.

\footnotetext{
* Corresponding author: abduloh@staff.Unsika.ac.id
} 
Character comes from English: character and in Greek, namely characin meaning "to engrave" (Ryan \& Bohlin, 1999). ${ }^{[3]}$ To engrave "means carving, painting, carving, or scratching (Echols \& Shadily, 1995). ${ }^{[4]}$ Indonesian dictionary the word "character" means character, psychic traits, morality or character that distinguishes one from another, and character, the person who possesses personality, behavior, nature, character, or character. Thus, the character is a behavior or, character and character of a person who can distinguish a person or individual with others.

Thomas Lickona argues character as " A reliable inner disposition to respond to situations in a morally good way, characteristic of moral knowing, moral feeling, and moral behavior" (Lickona 1991), ${ }^{[5]}$ Good character, including knowledge of goodness (moral knowing), which can generate motivation (commitment) to the good (moral feeling), and finally really do the good (moral behavior).

Learning is a process to achieve a purpose and purpose that can meet the expectations, the character of an individual in fulfilling and maintaining his life, and can provide useful value and benefits for the interests of all living things on earth that is characterized by the inheritance of culture and character that has been owned by society and nation. The process of learning culture and character, actively learners develop their potential, conduct the process of internalization, and the appreciation of the values into their personalities in socializing, develop a more prosperous society, and develop a dignified nation life with various processes of improvement and refinement various resources that support the educational process.

\section{Research methods}

Based on this the authors are interested and try to explain the theoretical study on the characteristics of education based on six value systems, with descriptive study method and literature review analysis focus on the study of "process of educational character based on six value system as follows: 1) value theologic, which is reflected among other things in the almighty god, pillars iman six pillars of islam five praying, monotheism, charity, forgiveness, prayer, sincere, repentance, ijtihad, focus istiqamah, and jihad fi sabilillah. 2) value ethical-legal, which is reflected among other things in a respectful, kind/humble, loyal, trustworthy, honest, responsible, good faith, fair faithful, peace, patience, forgiveness, helpfulness, tolerance and harmony. 3) aesthetic value, which is reflected among others, in a nice, clean, beautiful, pretty, sweet, charming, harmonious, romantic, and love. 4) value logical-rational, which is reflected in logic/match between facts and conclusions, right, appropriate, clear, tangible, identity/characteristics, process, circumstances conclusion match. 5) physic-physiological value which is reflected clearly its elements, functions, size, strength, changes, location, origin, cause and effect. 6) teleologic value which reflected embodied in a useful, beneficial, according to the function, developing/developed, regular/discipline, integrative, productive, effective, efficient, accountable, innovative. (S.Ahmad 2015). ${ }^{[6]}$

The goals of education in general at every level, from basic education to higher education, should be designed and implemented programmatically and systematically, so as to achieve goals in accordance with expectations. Formation of the learner character who have knowledge of religion, ethics, morals, and courtesy in interacting with the community, then 
education should be designed, implemented, and well evaluated (good governance) and education implementers can integrate character education in it to create human- Beings who have noble character. Kementerian Pendidikan Nasional. (2010) ${ }^{[7]}$

\section{Results and discussion}

Education is a process of various activities of the body and soul in effort to reach the purpose of educators and learners are expected, through the process of thinking and activity, physically active and creative and productive in solving problems that were able to find something that is useful and valuable (inovative) Abduloh $2017^{[8]}$. Process education caracter based on six value system, Individual characters can be influenced by environmental factors and innate factors of birth. Psychologically behavior is a character of the potential embodiments of Intelligence Quotient (IQ), Emotional Quotient (EQ), Spiritual Quotient (SQ), and Adverse Quotient (AQ), owned by individuals. The context of character totality in psychological and socio-cultural processes can be grouped into 1) spiritual and emotional development, 2) intellectual development, 3) sports and kinesthetic (physical and kinesthetic development), and 4) taste and intention (affective and creativity development). The character of this psycho-social process, holistically and coherently interconnected and complementary in the framework of character formation and the embodiment of noble values in a person. Character formation can be formed through the process of human learning from the environment, family, education, work and nature.

Character is the nature, character possessed by man, good and bad life order of a society can be determined by a character of individual that exist in that group, can be determined by character influencing attitude and behavior of human being. If the character appears positive it may have the benefit but if the existing character can harm others, it becomes a problem for the survival of human and nature. So for that in the learning process needs to be included values of characters that have value for both morally, mentally and spiritually to learners conducted by professional teachers/educators means teachers who are able to perform their duties and functions in accordance with the rights and obligations by applying and developing on six value systems in the education that includes;

1. Value theology, (god's value) in learning can be applied that is to form the character of beliefs (believing skills) on students in doing a good action determination, speech and behavior in life to do that in the learning process that is required though aeart or sense that is to form the skills of spiritual quotient (SQ), and adverse quotient (AQ) owned by individuals.

2. Value ethic-legal, (norms) in the lesson are expressed to establish the character of the disciple's learners, commitment, consistency and responsibility. That is by applying attitude skills (affective skills), among others, respect, good, faithful, trustworthy honest, responsibility, good faith, faithful, peaceful, patient, forgiving, helpful, tolerant, and harmonious. Namely through the application of various examples of educator behavior, and the environment. The ethical value can be applied to the students that is to nurture noble values such as respect for others, good, faithful, trustworthy honest, responsible, good faith, faithful, peaceful, patient, forgiving, helpful, tolerant and harmonious, it is teachers can apply it by giving examples of behaviors in learners which means educators or teachers must be a role model for learners. 
3. Value aesthetic, in the implementation of learning teachers can apply attitude skills, behavior (cognitive skills) is by giving examples of values that have artistic value and beauty so that learners can motivate learners formed spiritual quotient intelligence, that is through the application of various models, media methods, materials, and managerial as well as techniques and learning strategies. The aesthetic value, in character teaching, can be applied to the skill-making values of creating something beautiful that can make things beautiful, clean, beautiful, beautiful, sweet, attractive, harmonious, romantic, and loving. These values can be applied in learning by developing ideas, by actively thinking and creatively in developing various models, media, methods, teaching materials, managerial, techniques, and learning strategies that can enhance the aesthetic values of the participants educated, which means teachers should be able to learn, learners so that students are aware of the obligations and rights as learners.

4. Value logic (rational), in learning logical value learners are invited to think from something abstract to concrete and scientific either with the knowledge, belief, or with a characteristic or mark in the form of tangible changes, among others, logic / match between the facts and conclusions, exact, appropriate, clear, tangible, identities / characteristics, processes, states of conclusion match. It is the teacher's educator must be able to master the knowledge and broad knowledge that is by way of continuous learning.

5. Physical-physiological value in the learning process characterized can be applied by conveying something to the learners with something tangible that accompanied by facts and data that can explain elements, functions, size, strength, change, location, origin cause, cause-effect and so forth. This means that in this case educators or teachers can teach is to convey knowledge (transfer knowledge) to leaners in order to be able to create something in the form of real accordance with the role and function.

6. Teleology value can be applied in the learning activity of the learner is encouraged to do the learning activity to improve the skill in a piece of work, which has useful value and benefit for life according to its role and function, actively, creatively to build and develop by regular, discipline, integrative, productive, effective, efficient, and innovative, meaning that teachers or educators and learners should be sensitive and care about all the development of the environment.

So for that the authors propose the opinion that a teacher who can menghapakkan character education based six system values such as leaders who dare to GILA that is leader 1) Genius means to have ideas, ideas of knowledge and intelligence more than the under it in order to make decisions appropriately and fast. 2) Integrative leadership must dare to come down directly and merge united with subordinates to solve problems regardless of race or class. 3) Loyal leadership must have a devotion to the organization, or institution that is led. 4) Adaptive a leader must be brave and able to adapt to all levels of society in any situation and condition. Abduloh 2016) ${ }^{[9]}$. Just as in the implementation of learning that is required a teacher who can be a leader figure for learners, who are able to transfer and apply the learning character of six value system. Which can be described in the process of character education based on six systems as follows: 


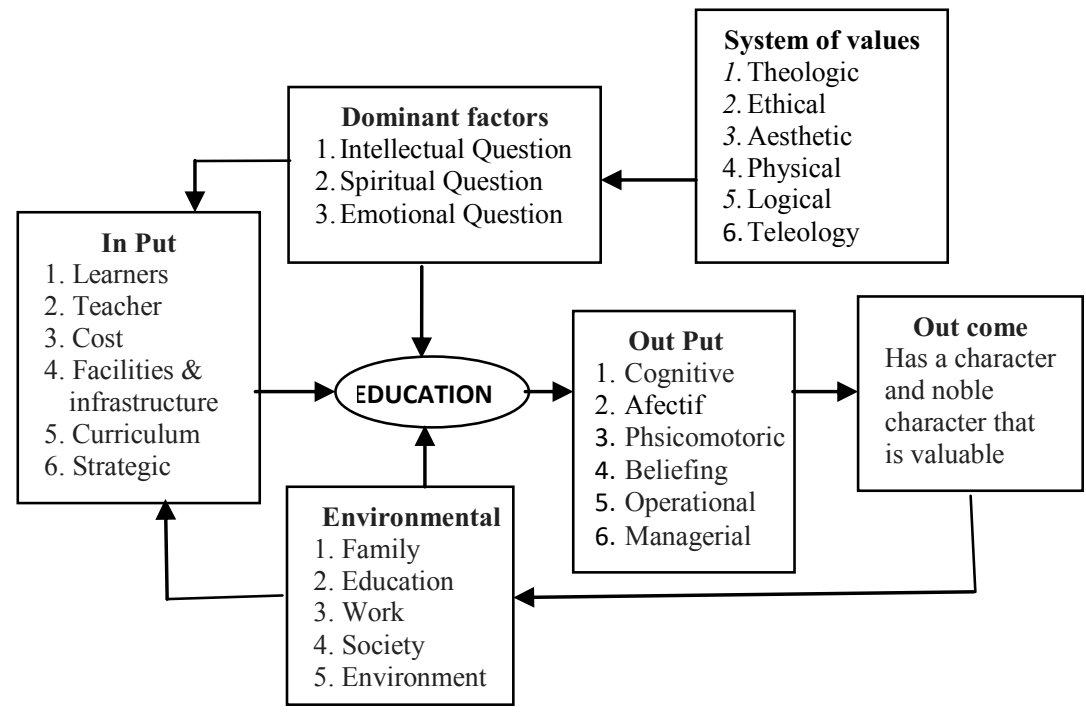

Future. 1 Process character education based on six value systems

\section{Conclusion}

Individual characters are formed due to a series of skill activities provided to the learner through a systematic and programmed learning process according to established standards including cognitive skills, attitudes skills, and behavioral skills (behaviors skills), As well as confidence skills, skills of use (operational skills) and managerial skills, especially in the application of the character of the learner can think and act something that refers to the six value systems that include the theological value (divinity), ethical (norm), aesthetic (beauty), logical (concreet), physiological (tangible), and teleological (used).

\section{Acknowledgement}

Thanking God for the presence of Allah Subhanahu Wa Ta'ala, regarding the completion of this article, please allow me to thank all those who helped petrify the completion of this article I say, thank you and appreciation submitted wholeheartedly with respect, and proud to:

1. To the Rector of Unsika who has given permission to participate in the Global Conference on Teaching, Assessment, and Learning in Education

2. To Undiksha Rector as organizer of Global Conference on Teaching, Assessment, and Learning in Education 2017

3. To Prof. Dr. Ni Nyoman Padmadewi as Chief Executive of the Global Conference on Teaching, Assessment, and Learning in Education 2017 which has provided an opportunity to participate in conferences activities. 
4. The revision team of GCTALE 2017 who has provided feedback for improvement to all conference participants

May all good deeds we always get affection from God Almighty Allah.

\section{References}

1. Abduloh. Leader Of Success In The Modernization Of Education the $1^{\text {st }}$ International conference on education in Indonesia (ICE). 167 (2016)

2. Abduloh. Creating Innovation In Education By Using Value Analysis System. The Fifth south East Asia Development Research International conference (5 ${ }^{\text {Th }}$ SEADR). 353 (2017)

3. Echols, M. John \& H. Shadily, English Dictionary Indonesia: An EnglishIndonesian Dictionary. Jakarta: PT Gramedia. Cet. XXI. 214, (1995)

4. Kemdiknas, Character Education Master Design. Jakarta: Ministry of National Education. 9 (2010)

5. Ryan, Kevin \& Bohlin, K. E. Building character in Schools: Practical Ways to Bring Moral Instruction to Life. San Francisco: Jossey Bass, 5 (1999)

6. A. Sanusi, System Value Alternative Wajah-Wajah Pendidikan Bandung Nuance Cendikia , 35 (2015)

7. Thomas Lickona, Educating For Character: How Our School Can Teach Respect. And Responsibility (New York: Bantam Books, 51 (1991), 